\title{
Desvendar, esclarecer - Literatura e Medicina em Fernando Namora
}

José Manuel Mendes

Presidente da APE e escritor

Resumo: Partindo do “livro" Deuses e demónios da medicina, de Fernando Namora, explora-se neste ensaio o diálogo crítico entre o autor/médico e a sua obra, procurando intersecionar, de forma ampla, os campos da medicina e da literatura. Discorrendo, pela via da analogia ou da dissonância, acerca de diversos livros do autor, releva-se a unidade que subjaz a um percurso evolutivo de grande coerência. As vinte e uma "biografias romanceadas" de médicos, que constituem o referido livro, atestam um modo efabulatório de narrar, que se reencontra na totalidade da obra do escritor, médico e intelectua.

Palavras-chave: biografias, efabulação, diálogo, unidade, evolução

\begin{abstract}
Through a study of the "book" Deuses e demónios da medicina, by Fernando Namora, this essay explores the critical dialogue between the author/doctor and his works, seeking a broad convergence between the fields of medicine and literature. The discussion of several books by the author, by way of analogies or dissonances, will highlight the unity that underlies his evolutionary path as one of great coherence. Accordingly, the twenty-one "romanticized biographies" of doctors, which constitute the referred book, testify to particular plot building strategies which can be found in the entire work of the writer, doctor and intellectual.
\end{abstract}

Keywords: biographies, plot building, dialogue, unity, evolution 
Quando surge, em 1952, Deuses e Demónios da Medicina,' Fernando Namora é um escritor reconhecido pelo percurso que, da poesia inicial aos romances, novelas e narrativas, se destacara já no contexto cultural. A 1 a série de Retalhos e os títulos que a precederam, tal como o que se lhe seguiu, tinham colhido uma recepção crítica assinalável, interesse em crescendo dos leitores, o prestígio do insubmisso conferindo à arte a energia de um humanismo não desvinculado de exigências formais nem da densidade do vivido. Jacinto do Prado Coelho dirá adiante, ${ }^{2}$ em tempos de estruturalismo e correntes conexas: "Com teóricos e ensaístas (...) aprendi que o autor fora da obra não interessa ao estudo do texto (...); que é o acto da escrita, não o autor, quem faz a literatura; que sentimentos, ideias, propósitos nada têm que ver com a literariedade e a qualidade, o valor literário. Sei tudo isso; mas, ao falar de Namora, algo existe de muito profundo que me obriga a não dissociar a obra escrita do autor cuja mão a escreveu. Impõe-se-me como evidência não só a unidade do conjunto da sua produção literária como a solidariedade entre esta e um pensamento vindo das entranhas, um modo pessoal de ver, de sentir, de se comportar na vida. Namora é das raras e mais perfeitas encarnações do clerc na literatura de hoje."

É acima de tudo o intelectual, admirado nos jornais e ensaios, médico, quem Livros do Brasil convida a elaborar, dentro de moldes e prazos apertados, um volume para a colecção Vidas Célebres que programara. Não iam longe os anos da Faculdade, Coimbra, em que a História sumária do exercício clínico e dos inventos e lições a ela associados - com inscrição curricular - Ihe merecera peculiar apreço, acabava de ingressar no Instituto Português de Oncologia ao abrir da década e motivações subjectivas se reuniam para assumir o projecto, cedo considerado "um desvio que talvez se não repita”, "apaixonante embora" (Duas Palauras, prefácio à edição inaugural). E isto porque "um livro digno" da admirável "gente" escolhida "pediria" o que não obteve: "meses ou anos de consultas, de pacientes pesquisas (nada fáceis e nada acessíveis neste caso particular (...) para terminar num agradável trabalho de recriação; de outro modo, como é o caso presente, por razões várias, tivemos que reduzir as ambições” a um labor “de compilação, despersonalizado, em que se arrumaram ou resumiram dados dispersos, que o leitor teria certamente dificuldades em coligir."

Só a $3^{a}$ edição, "refundida e ampliada”, ${ }^{3}$ apagaria o travo - apesar do êxito que até então se consolidara. Na nota introdutória (Duas Palauras Reincidentes ao Leitor Desprevenido), Fernando Namora previne, com excesso de escrúpulo porventura: "Na metamorfose que ora vem a lume, mais avantajado - obrigando a dois tomos -, mais sereno e também com recheio de outra monta, nem por tal cerzidura Deuses e Demónios da Medicina deixa de ser um livro novo de pano velho.” O proémio será retirado a partir da reedição de 1977 : a anamnese do empreendimento estava feita, aos leitores dar-se-ia um percurso de paisagens existenciais e científicas dos 21 protagonistas seleccionados, ${ }^{5}$ de Hipócrates, Galeno, Paracelso e Laennec a Virchow, Koch, Ribeiro Sanches (o único português na Enciclopédie), Mesmer, Freud ou Fleming, sem colocar nenhum em zona de sombra. 
Biografias, portanto. ${ }^{6}$ Sondagens, rastreio de fragmentos vindos da tradição validada e dos arquivos documentais, desenho de retratos em que a mão pictórica se não exacerba nem oculta. Desde a crisálide, sob forte tempero romanesco. 0 que não afasta duas observações: a opção pelas estratégias do ficcionista, fora de quaisquer constrições, vincula-se à premência e verdade dos factos; a uma tal via são alheios os terrenos de matriz ou deriva hagiográfica, fantasiosa, denegatória, frequentes na produção (só distanciadamente) congénere.

Um parêntese para recordar uma certa a-canonicidade das indicações genológicas que acompanham a bibliografia de Fernando Namora: narrativas (Retalhos), narrativa literário-sociológica (Estamos no Vento), crónica romanceada (Diálogo em Setembro), crónica (URSS Mal Amada, Bem Amada), cadernos (para os diversos Cadernos de um Escritor), divertimento (Resposta a Matilde), como se, num espaço de atrito, jogo, dúvida e desafio, seguindo um propósito fusional, deixasse ao critério do intérprete a decisão adequada. Ou, afinal, lhe dissesse à maneira de Shakespeare: As you like it, sustentando todavia, numa direcção não difluente: "A delimitação entre géneros literários tornou-se difusa ou estilhaçou-se". ${ }^{7}$ Uma tal infixidez, transumância se se quiser, avulta nesta passagem de $O$ Rio Triste: "Devo ponderar um pouco mais em tudo isto, o Faria Gomes é uma personagem, é todo um núcleo de uma Lisboa a pedir cronista. Quem sabe se tenho nas mãos um romance?"

O travejamento eleito não padecerá, no transcurso das unidades agregadas, arritmias hiper-factualistas, quebras na fluidez compositiva, desequilíbrios tensoriais do verificável com o imaginário, impasses, desacertos no doseamento dos ingredientes convocados. Existem personagens vigorosas e secundárias, actantes, no entrecho, efabulação, conflito, descrições e lugares, marcadores espácio-temporais, variabilidade de ritmos e recursos discursivos, diálogos que são interagentes ou tradutores das rudes atmosferas sócio-psicológicas em que toda a ousadia criadora se insere. Estes homens, quase sem excepção, provaram a garra das incompreensões e dos anátemas. Porque puseram em causa o inquestionável e predicaram relevantes isotopias do futuro.

A talhe de foice (como ainda se dirá), transcrevo, leio:

- “Os filósofos gregos que se foram interessando pela medicina estabeleceram uma ponte entre a medicina mais rudimentar da época de Homero e a medicina do tempo de Hipócrates. Na escola de Tales, e sob o estímulo desses filósofos, pela primeira vez se investigam na natureza as motivações dos fenómenos que alteram a harmonia do organismo e se procuram as leis que os regulam, descobrindo-se entre os vários ramos da ciência uma íntima correlação.” Um tónus informativo, síntese e nudez expositiva.

- "Chegara o momento de Galeno ['médico das grandes personagens de Roma'], vaidoso e arrogante] ter de pagar um tributo quase inevitável e exigido em todas as épocas aos triunfadores: a perfídia dos medíocres, a aleivosia orquestrada dos profissionais da insí- 
dia, o surdo despeito dos amigos. A cada passo se lhe atravessava o rancor daqueles que sentem na popularidade alheia uma afronta pessoal." Seguem-se, narração desveladora e judicativa, sequências que caracterizam o meio, nos planos social e de classe sem emulação sadia, antes da viagem a Chipre.

- "Bárbara noite de S. Bartolomeu. (...) 0 rei aconselhara Paré [barbeiro e "primeiro cirurgião do mundo's] a fazer-se católico sem demora, a fim de o precaver contra a violência de qualquer antagonista obcecado.

- Pela luz de Deus, sire, eu penso que estais lembrado da promessa de nunca me ordenardes quatro coisas: reentrar no ventre de minha mãe, encontrar-me a um dia de distância de uma batalha [em numerosas se notabilizou], deixar o vosso serviço e ir à missa.

0 rei mostrou-se agitado. E numa voz em que mal dissimulava a insónia e a inquietude desses dias, remordido por um sentimento de culpa, confessou:

- Não sei que se passa comigo. Acho-me perturbado de corpo e de espírito, como se tivesse febre. E parece-me a todo o momento, quer desperto quer a dormir, que esses corpos massacrados me procuram de faces horrendas e cobertos de sangue. Eu bem desejaria que neles não se incluíssem os pobres de espírito e os inocentes.” E a trama não prescindirá, neste como nos demais lances, dos mecanismos ficcionísticos que absorvem, aprofundam, iluminam a inervação dos dados coligidos.

- “Deparou-se-lhe um velhinho respeitável [comissário de polícia, que o chamara], que o recebeu friamente e, sem mais preâmbulos, o fez passar a outro aposento, onde the mostrou o cão que fora operado [e era seu].

- Conhece-o? - e um dedo justiceiro do beleguim apontava a torturada vítima.

Claude Bernard, refeito da surpresa, anuiu:

- É, de facto, o cão que se escapou do laboratório. E confesso-me muito satisfeito em reencontrar a minha cânula [de prata], que supunha perdida.

A desfaçatez da resposta indignou o comissário.” O confronto não durará, serenado o homem da farda com a certeza de que o animal ficaria sem sequelas. Cães-cobaias, a vivissecção, os avanços nos desvendamentos fisiológicos, e o leve humor do relato.

- "No meu laboratório passou-se algo de curioso: temos em cultura um fungo que mata os estafilococos. Não quererá ensaiá-lo?

O cirurgião[Craddock] anuiu em que se cobrisse a superfície da amputação com uma compressa do filtrado, mas o efeito foi nulo, pois a infecção [septicemia] generalizara-se. O malogro não poderia desanimá-lo. 0 que precisava era de obter o princípio activo numa forma concentrada e estável. (...) Recorreu improvisadamente a Ridley, um moço com pendor para trabalhos desse género [bioquímicos]; talvez que ele, com a colaboração do seu devotado Craddock, conseguisse desembaraçar a substância das proteínas estranhas causadoras de acidentes anafilácticos, de modo a poder ser utilizada em injecção, e conseguisse extraí-la e concentrá-la para o mesmo efeito.

- Que nome havemos de dar à nossa substância, Craddock? - E sem esperar por um alvitre, acrescentou: - Mas o nome é óbvio: penicilina. Vamos a isto.” Investigação, experi- 
mentalidade, epifania decerto. 0 registo estético, consciente do seu engenho revelador, confere a este passo decisivo a marca das conjunções multidisciplinares que amiúde, nos obscuros e frescos pretéritos como no presente, determinam a constituição do arsenal terapêutico para combate às patologias e mitigação dos transtornos e sofrimentos de quem as contrai.

Os extractos transcritos, acabados de ler, expõem a construção fabular, a ductilidade dos processos enunciatórios e a linha de subtileza no esculpir de figuras em que os contrastes afloram - talento, brilho ou insegurança, ousadia, aprumo cívico, desregramento, egoísmo, acção solidária, pertinácia na superação do adverso como na conquista do impossível. Mas o médico Fernando Namora, com uma argúcia e competência além dos manuais, não esteve ausente desta "maravilhosa aventura humana". Impressionam a vastidão dos seus saberes específicos, a limpidez dictiva (que, dirigida ao leitor comum, não abdica do rigor técnico - em traços gerais como nos pormenores), a pulsão inclusiva e formadora. De Hipócrates (o juramento que Ihe fixou indexado subsiste como pauta deontológica, entendida vezes sem conta na base de um literalismo anacrónico), Galeno ou Avicena, cujas intuições e regras também cruzaram séculos, a disciplinas em embrião ou aprimoramento. Umas quantas, no meio de individualidades exaltantes, conduzem-nos ao desbravar de trilhos anátomo-fisiológicos, cirúrgicos, diagnósticos, à hematologia, aos estudos e realizações da saúde pública, da psiquiatria, da oncologia ou dos instrumentos terapêuticos pré e pós-farmacológicos. A aura de Paracelso (um pseudónimo universalizado), Paré, Virchow, Koch, Mesmer, Freud, Fleming, não menorizando os seus pares neste painel, pela axiologia - a adstrição ao bem, à verdade, em instâncias de auto-superação nos trajectos vital e científico, por uma simbiose de inventiva e audácia na descoberta de contributos fulcrais, interceptam as apetências do "médico prático"ı Fernando Namora, acutiladas, enriquecidas no desempenho funcional, os as áreas do convívio historicista e teórico tão a seu jeito.

A medicina como matéria da literatura, a literatura como uma das ferramentas da medicina. (Nesta, a história clínica e os modelos narrativos adquiriram ênfase impostergável, mesmo na contemporaneidade das híper-especializações e nano-ciências.) Intercomunicação de galáxias, à margem da atrofia identitária ou dos mecanicismos, estimuladora numa contextura de fluxos autónomos. E livres. Não, como se depreende das vulgatas a respeito, dependência e bilateral pauperização - arredando temáticas outras, multímodas em Fernando Namora.

As biografias romanceadas de Deuses e Demónios cabem numa réplica do Autor a Baptista-Bastos": "Todos os livros que venho publicando são de um ficcionista. ${ }^{12} \mathrm{Ou}$ incluem novelas e contos ou são literariamente organizados segundo os habituais ingredientes romanescos: personagens, lances, situações efabuladas, textura narrativa ficcional, etc. Não sucederá isso em Diálogo em Setembro, A Nave de Pedra, Estamos 
no Vento, Cavalgada Cinzenta?" São, nesta conformidade, apenas um elo da cadeia de contactos entre a ficção e a medicina, despontada em Fogo na Noite Escura, assídua no decurso da bibliografia que Jornal sem Data e Dispersos culminam - ora enquanto diegese sob impulso vivencial, mas não autobiográfico stricto sensu, sublinhe-se (Retalhos da Vida de um Médico, O Homem Disfarçado, Domingo à Tarde, Cadernos [“A Vacina”, "A Consulta”] ${ }^{13}$ ), ou reflexão teorético-procedimental, ${ }_{1}^{14}$ extensível à enfermagem, ${ }^{15}$ ora em asserções avulsas, ditadas por circunstâncias evocativas ${ }^{16}$ ou por injunção de ofício. ${ }^{7}$

Biografias, reconformar de vidas que foram únicas, irredutíveis - dissipando brumas enredadas na lenda, no abscôndito, nos silêncios pardos das lápides, nas fuligens da irrelevância. Vidas à mercê, aqui, de um denso caudal novelístico. Não excurso científico-técnico por mapas de cometimentos, impasses, sucessos no âmbito da historiografia medical. Por isso, Pedro Nava pôde exarar, no Jornal do Brasil (17): "Estamos lendo não a anedota (...), o acaso, a contingência ou o acidente de uma vida humana, mas o largo e extenso romance de uma das mais prodigiosas aventuras da inteligência.” Ou, entre nós, Alberto Ferreira (17): "A caminhada da medicina desde Hipócrates (...) é tão magistralmente traçada, tão dramaticamente narrada, que acaba por se cristalizar num livro de um humanista, de um pedagogo.” E, para restringir as nótulas críticas, Taborda de Vasconcelos (18): “A leitura de Deuses e Demónios da Medicina - o que o título tem de significativo a ninguém escapa - assemelha-se quase à visita a um museu de raridades, povoado de animadas figuras, buliçosas e atrevidas em seus desígnios e processos, carreando para o rol das maiores aquisições humanas o seu grão de areia.”

Mário Sacramento intitulou assim o VII capítulo da sua monografia sobre Fernando Namora: De médico-escritor a escritor-médico. A transição permite conceber ténues fronteiras: entre 1942 (licenciatura, consultório em Condeixa) e 1965 (termo do cargo de assistente do IP0), período do esculápio, nas Beiras e em Lisboa - que não inclui, como deverá, a juvenília (Cabeças de Barro, com Carlos de Oliveira e Artur Varela, Relevos, As Sete Partidas do Mundo, Mar de Sargaços), e se manifesta discutível, pese embora a operatividade das demarcações cronológicas; entre temários mais propiciados pelo mister da bata branca, de que Domingo à Tarde seria a empresa derradeira, e os que buscaram, ampliando, horizontes inabordados de "inventariação do homem português”, nos arredores e seguimento de Diálogo em Setembro, 1966; entre a prevalência do vocacional - varrido o turbilhão do ingresso na Universidade ${ }^{21}$ -, vivenciado, imperativo, e os destinos (audácia, complexidade) de quem se implicou numa safra gnosiológica, no descriptar de mudanças da tecidura humano-política advinda com o Estado Social, na percepção da "era do vazio" 22 e das novíssimas narrativas, afluentes ou não da era pós-moderna. Colocada a questão, que continuará em aberto, vale, sem submissão a qualquer paradigma autoral-normativista, ouvir Fernando Namora. Dois instantes somente: 
- "O mais certo é o médico ter influenciado o escritor tão vincadamente como o escritor influenciou o médico. Mas, em termos existenciais, digamos assim, suponho que, dessa influência mútua, perdurou o médico. A medicina (...) marca-nos a fogo". ${ }^{23} \mathrm{Em}$ termos existenciais, precise-se - franqueando a porta a conclusões diferenciadas, por ele admitidas e aceites, v.g. no campo da exegese literária. Eduardo Lourenço, que subscrevo: "Si le métier lui fut une occasion de remettre em cause l'existence même du médecin, la maladie et ses fantômes arrachèrent l'écrivain au piège du contentement mortel de soi. À la surface de ce trouble des profondeurs, une étrange et rassurante présence demeure: celle de l'écriture". ${ }^{24}$

- "A medicina, mesmo aos retraídos como eu era ou sou, predispõe à receptividade, ao solidarismo activo, e entrega-nos as chaves que abrem os esconderijos menos acessíveis, lá onde o homem é verdadeiramente o que é. Porém, esse jogo ambíguo e difícil de prolongar, ser médico para servir o escritor, teria de chegar a um termo".25

Do Relatório da Casa do Povo de Tinalhas, nos primórdios da carreira (1943), incisivo desnudamento sócio-antropológico da aldeia numa perspectiva de saúde pública $^{26}$ às meditações contidas em Jornal sem Data e Dispersos, dos artigos de especialidade a Retalhos da Vida de um Médico, la e $2^{\text {a }}$ série, O Homem Disfarçado e Domingo à Tarde, ${ }^{27}$ sobre os quais me não deterei - deduzo que o farão Fernando Batista ${ }^{28}$ e Júlio Machado Vaz - irão distâncias apreciáveis, de índole, execução e crescente esmero formal, mas não se turva a incindibilidade rastreada, patente inclusive nas projecções autobiográficas e, com menor incidência, homo-autorais nos últimos quatro livros arrolados.

João Eduardo e Jorge, como o narrador de Retalhos ou Zé Maria (Fogo na Noite Escura) não emanam de uma pulsão especular, uma receita egográfica do homem -médico, cidadão, prosador Fernando Namora - que havia cinzelado trajectórias de confluência: empirismo e solta invenção, exame dos detalhes férteis e dinâmicas da representação tipológica (insubjugável a ditames veristas e afins); plasma memorial e quanto o excede e demuda. Num (neo)realismo lavrado pelo acentuar das encruziIhadas do eu (escrutínio, libertação), sob incentivo existencialista, estas duas personagens ${ }^{29}$ não se confundem, anulam ou contaminam, partilhando, contudo, crestas afectivas, solitudes, "vidas secas” ${ }^{30}$ pela teia do banal e da incomunicação numa comunidade de ilhas sem arquipélago gregário.

João Eduardo, adormecidos ou em eclipse os ideais da juventude, sofre, no vértice da reputação, duros embates introspectivos e ético-profissionais (a cena da criança entalada no elevador, defronte da sua inércia, e o serão em casa do professor Cunha Ferreira não se esquecem), algures incaucionando o baronato corrupto, o visco das rotinas, as redes de cupidez em riste, a alienação da tribo por consultórios, clínicas, hospitais debaixo de azorrague estatístico e desumanizante, algures assentindo 
com a lisura de Medeiros e a honorabilidade resgatadora de Jaime, cujo perecimento reacende o gume imperioso de uma viragem: o rasgar das máscaras que envergava, um re-apego aos princípios que o afeiçoaram, a abolição da indiferença, dos embustes, das simulações, uma revalorização do desvaliado. ${ }^{31}$

Jorge, “le cynique, qui tous les jours côtoie la mort”, ${ }^{32}$ por seu turno, emergindo de um magma de dissimulações, disputas, renúncias, perda da alteridade (sem a qual a praxis médica se desnatura), ocupa o centro de um abalo ontológico, induzido por Clarisse, a doente que uma leucemia devasta. Ao longo do enlace amoroso de ambos, ela viverá a própria morte - da negação à revolta, dos cromatismos negociais à voracidade de um ocaso a plenos haustos, fendido inexoravelmente pela agonia, ${ }^{33} \mathrm{e}$ confrontará o “tipo insociável”, brusco, neurasténico, petulante, roído de descrença, sem armas para derrotar o cancro, com a consciência em crise, elidível ou atenuável por translação humanística. Jorge será outro, rente ao que fora ou entretanto a nascer, feita a ruptura com os automatismos (auto-defensivos) da desistência, "possuído por uma estranha e revelada tranquilidade”: "Les patients de Jorge, au terme de cette expérience, ne seront plus des morts-vivants, des incurables, mais ces vivants condamnés à mort qu'au bout du compte nous sommes tous". ${ }^{34}$ Les patients: "cemitério de vivos”; mortos-vivos, vivos-mortos. "Eram já mortos? Ainda eram vivos?” (Vladimir Jankélévitch numa proposição oblíqua: “C’est la présence latente de cette mort qui fait des grandes existences, qui leur donne leur feveur, leur ardeur, leur tonus. On peut donc dire que ce qui ne meurt pas ne vit pas.”) E, no entanto, Clarrise - na fase da irresignação: "Morte, morte!, foi a única palavra que the ouvi dizer! Já ninguém sabe, aqui, falar de outra coisa?"

João Eduardo, Jorge, o narrador de Retalhos: a periferia dos “casos clínicos”, para subscrever Óscar Lopes, diante de agudos “casos de consciência”, pujantes de implicações nas esferas privada e relacional dos heróis ficcionados, e, com inusitado bisturi, as castas de diversiva etiologia, os pobres, a iniquidade dos tempos opressivos.

O bosquejo não escalpeliza, reafirme-se, preservando eu o norte magnético do tema, a riqueza, espessura, capilaridade de domínios (nunca se tinha ido tão ao cerne na dissecação dos “meios médicos e hospitalares ${ }^{35}$ ), profundidade de diagnose psico-social inscritas nas recensões, peças académicas, abordagens que as obras sindicadas espoletaram. Teve em vista, ante omnia, esclarecer que não há nestas, as obras, um clínico prototípico, muito menos decalcado na tarimba do autor por colmeias rurais (onde foi e não foi João Semana ${ }^{36}$ ) ou ambiências citadinas, e, de acordo com o que pude extrair da conferência durante a manhã proferida pelo meu dilecto António Pedro Pita, na parte referente a quanto se segue a Diálogo em Setembro, dilucidar uns tópicos finais:

- A medicina, quer num entalhe praxológico, quer extensão do concreto sob reparos, actualizações, inconformismos, quer recorrência memoriável, amiúde se nos depara nas 
páginas dos Cadernos, cronísticas e romanescas que vão até Dispersos ${ }^{37}$ - como, ademais, o "olho clínico" (focagem pontual ou insight) e o léxico que nos acolhe em inúmeras latitudes: certo "dedo virulento", “um perturbante parentesco entre (...) aparelhos [cibernéticos] e o sistema nervoso humano". ${ }^{38}$

Suspendo no átrio a digressão que planeara. Com a travessa melancolia de ter preterido, pela pragmática do Colóquio, sulcos e incisões curiais. Fiquemos nesta pedra corroída, sub tegmine fage - Fernando Namora, no prefácio a Casa da Malta, de 1961, a tantos níveis saliente: "O médico não foge para a arte: antes a procura como irrefreável instrumento da sua densa experiência, e procura-a porque ela the formula e ilumina a sua condição de homem colocado numa zona privilegiada de convívio. Assim, medicina e arte completam-se: uma, desvenda, fornece a matéria prima e a temperatura emocional: a outra, o esclarecimento." Alhures nos reencontraremos. Bem hajam.

\section{Notas}

* José Manuel Mendes, professor universitário reformado, Visiting Professor da Escola de Medicina da Universidade do Minho, cujo Conselho de Curadores integra. Autor de extensa bibliografia em diferentes domínios. Presidente da Associação Portuguesa de Escritores. Membro de júris literários internacionais, com relevo para os Prémios Reina Sofía (poesia), Fernando Namora e Agustina Bessa Luís (narrativa), DST (poesia e narrativa) e Vasco Graça Moura (cidadania cultural). Sócio de diversas instituições, entre as quais a Academia das Ciências de Lisboa.

' A revista Clínica Contemporânea (Tomo V - No 8 - Outubro de 195I) insere, em pré-publicação, a versão primeva da biografia de Ambroise Paré. Em nota, logo na página 427, a de abertura do texto, lê-se: “Do livro Vidas de grandes Médicos, no prelo.” Foi este um título inicial, provisório, de Deuses e Demónios da Medicina.

As obras de Fernando Namora mencionadas, bem como os fragmentos transpostos, reenviam para a edição do Círculo de Leitores, Lisboa, Obras Completas, saída entre 1996 e 1999.

2 Jacinto do Prado Coelho, Ao contrário de Penélope, Livraria Bertrand, Lisboa, 1976.

${ }^{3}$ Editora Arcádia, Lisboa, 1963.

${ }^{4}$ Círculo de Leitores, edição de novo refundida, profusamente ilustrada, em dois tomos de formato álbum. Na colecção Obras de Fernando Namora (Editorial Caminho), Deuses e Demónios da Medicina será pela primeira vez publicado num só volume.

${ }^{5}$ Outros perfis de médicos, portugueses em geral, percorrem as páginas de alguns Cadernos: Francisco Gentil (Um Sino na Montanha), Fernando da Fonseca (A Nave de Pedra), e Egas Moniz (Jornal sem 
Data), por exemplo. Fernando Namora chegou, de resto, a considerar a hipótese de um terceiro andamento da jornada principiada no dealbar da década de 50.

${ }^{6}$ Philippe Lejeune (Le Pacte Autobiographique, Seuil, 1975; Signes de vie, Seuil, 2005; Les bouillons de soi, Seuil, 1998 [as datas reportam-se às edições compulsadas]); Clara Rocha (Máscaras de Narciso. Estudos sobre a Literatura Autobiográfica em Portugal, Almedina, Coimbra, 1992); Paul John Eakin (Fictions in autobiography. Studies on the art of self- invention, Princeton University Press, 1985) e André Maurois, escritor, biógrafo (Alain, Voltaire, Proust, Turguéniev, Byron ou, não sendo exaustivo, George Sand) e ensaísta (Aspects de La Biographie, Grasset, Paris, 1928; L'art de vivre, Plon, Paris, 1939) estruturarão, nesta sequência, a matriz, os elementos configuradores e modos de apuramento do género - ou sub-género? - em análise (na base da distinção a fazer entre autobiografia e biografia), icebergue que, na economia desta comunicação, mal se divisará.

${ }^{7}$ Encontros, entrevistas. (।a edição, Editora Nova Crítica, Porto, 1979)

${ }^{8}$ Ambroise Paré - de Barbeiro a Primeiro Cirurgião do Mundo foi título da publicação inicial (Clínica Contemporânea, acima referenciada [ı]).

${ }^{9}$ Na dedicatória a partir da $3^{a}$ edição:

“À Zita, que colaborou na primeira versão deste livro;

à Minducha, que nele entreviu o significado e as peripécias da medicina;

à Margarida, que o leu como maravilhosa aventura humana." (itálico meu)

${ }^{10}$ Médico prático era designação corrente à época do quotidiano profissional de Fernando Namora, que só em 1965 abandona para prosseguir, quase a tempo inteiro, a obra literária. Acresce que a usou com propriedade, quando necessário, sobretudo nos escritos técnicos. Um exemplo, aliás notável: $O$ médico prático perante o cancro do pulmão - Clínica Contemporânea - Volume VI, NOS I e 2 - Julho 1952.

" Encontros, entrevistas. (।a edição, Editora Nova Crítica, Porto, 1979)

${ }^{12} \mathrm{O}$ enquadramento temporal, 1978 (40 aniversário de As Sete Partidas do Mundo), e o fio do diálogo escolheram a narratividade como predominância na escrita do entrevistado. Não estranha o apartamento dos livros de poesia - sobre a qual, também num dos Encontros, faz incidir visões assertivas. Como esta: "Foi o poeta que, com frequência, abriu o caminho ao prosador e the anunciou algumas viagens, como sucedeu com livros como Terra e Marketing”. A que importa juntar, não obstante as atmosferas memoriais e intimistas, Nome para Uma Casa, 1984, precedente e coetâneo, nos tempos da consecução, de Resposta a Matilde, 1980, e O Rio Triste, 1982.

${ }^{13}$ A Vacina - Um Sino na Montanha, 1968. A Consulta - A Nave de Pedra, 1975.

${ }^{14}$ O doente, nosso hóspede, A Nave de Pedra, secção A Medicina e a Vida. Jornal sem Data, 1988 - o texto de abertura.

${ }^{15}$ Enfermagem, profissão indesejada - A Nave de Pedra / A Medicina e a Vida.

${ }^{16}$ Mestre Francisco Gentil, Um Sino na Montanha. Fernando da Fonseca, A Nave de Pedra. Numa linhagem confluente, Dispersos/2 - a Autobiografia, que antes fundara (1987) a Colecção "Autobiografias" das Edições "O Jornal”.

${ }^{17}$ Fernando Namora deixou esparsos centenas de artigos, nunca coligidos por expressa vontade sua, em publicações do foro profissional, com destaque para Boletim do Instituto Português de Oncologia (onde publicou, em 1951, Memórias Imaginárias de um Médico, cedo abandonadas, como abandonados 
foram os Arquivos Implacáveis de João Condê) e Jornal do Médico.

${ }^{18}$ Badanas da 6 a edição de Deuses e Demónios da Medicina, Livraria Bertrand, 1979.

${ }^{19}$ Badanas da 6 a edição de Deuses e Demónios da Medicina, Livraria Bertrand, 1979.

${ }^{20}$ Apud Mário Sacramento, Fernando Namora - Colecção A Obra e o Homem, Arcádia, Lisboa, 1967.

${ }^{21}$ Autobiografia: "Eu teria preferido o curso de Arquitectura, meus pais teimavam na Medicina. Como protesto, uma decisão inesperada: apresentei-me a exame de admissão a Engenharia. Meu pai veio a Coimbra dizer-me que a minha mãe estava enferma, desgostada da minha teimosia. Fui vencido.”

${ }^{22}$ Gilles Lipovetsky, L’ère du vide, Gallimard, Paris, 1983.

${ }^{23}$ Encontros, entrevistas. (।a edição, Editora Nova Crítica, Porto, 1979)

${ }^{24}$ Fernando Namora, Les Journées d'um Médecin - Avant-propos, Presses Universitaires de France, Paris, 1974. Referencie-se uma edição anterior de Retalhos da Vida de um Médico, la série: Carnet d'um médecin de campagne, Nouvelles Éditions Latines, Les Maîtres Étrangers, Paris, 1955.

${ }^{25}$ Encontros, entrevistas. (ןa edição, Editora Nova Crítica, Porto, 1979)

${ }^{26}$ Do Relatório: "Nas tentativas de legislação da assistência nos meios pequenos, é preciso considerar o rural não como uma coisa, mas como um ser humano." Ou, apesar da amálgama de "conflitos pequeninos e da insuficiência de meios técnicos e materiais”, das “desinteligências da política local”, impor-se-ia a “criação de 'coisas reais', maternidades, lactários, creches”, “o povo estaria pronto a colaborar e a ceder" nas desconfianças, nos ressentimentos, no apego a crendices ancestrais.

${ }^{27}$ Sobre Retalhos da Vida de um Médico, O Homem Disfarçado e Domingo à Tarde escrevi peças crítico-ensaístas à espera de refundição e (im)provável regresso editorial. Nelas pretendi, designadamente, na linha do que agora sustento, refutar teses no sentido da congenialidade do espaço autobiográfico e da ficção do autor. Mesmo Retalhos, com todo o peso da coisa vivida ou observada na nascente (nem sequer, amiúde, tão prevalente como se ajuizou), exubera de indicadores categoriais da narrativa enquanto reconfiguração, metamorfismo e arte do imaginário. [Estas são obras que, entre outras, anualmente trabalho com os alunos da Escola de Medicina da Universidade do Minho, actividades na vertente de Ética e Literatura no âmbito da Área Científico-Pedagógica “Humanidades em Medicina”].

${ }^{28}$ Ler, de Fernando Teixeira Batista, Fernando Namora - Retratos Ficcionais de um País Real, Edições Húmus, 2016.

${ }^{29}$ Personagens principais no desenvolvimento dos romances em que se integram. Ver Vítor Aguiar e Silva, Teoria da Literatura, Almedina, Coimbra, 1986.

30 Título do romance de Graciliano Ramos, Portugália Editora, Lisboa, 1960.

${ }^{31}$ Tradução francesa: L’Homme au masque. Sobre a temática da tradução, coonestando esta nótula, ver, nomeadamente, Umberto Eco, Dire quase la stessa cosa, Bompiani, Milano, 2016, e Hans-Georg Gadamer, Warheit und Methode, Tübingen, 1960. Da edição italiana (Verità e método, Bompiani, 1995), a que agora utilizo: "La traduzione, come ogni interpretazione, è uma chiarificazione enfatizzante".

Ainda: a incidência introspectiva foi sempre averbada na recepção ao romance, no país e fora dele, sem prejuízo das suas dimensões crítico-insurgentes (*) ou atinentes à solidão e desfiguramento do homem nas sociedades da anonímia.

- Urbano Tavares Rodrigues ( $v d$. nota 20): “O Homem Disfarçado é talvez a mais funda e complexa descarnação de uma consciência que o nosso século viu em Portugal. (...) Abre uma perspectiva ter- 
rível - terrível é a palavra - sobre os meios médicos e hospitalares, num corte vertical das vísceras e dos espíritos."

- Europe, Paris ( $v d$. nota 19): “Um brilhante romance psicológico." Ou (Les Nouvelles Littéraires, Paris: "A psicologia é de uma profunda verdade."

- Jean Espichel, recensão que acompanha o romance a partir da $3^{a}$ edição, na sobrecapa e, depois, como prefácio: "Uma evolução radical como esta, a passagem da pintura rústica à análise psicológica da condição humana sob um plano universal (...) representam uma raridade na literatura lusitana moderna."

(*) Tais dimensões eram axiais à escrita de Fernando Namora, mesmo que um cepticismo radical lhes latejasse na base. Leia-se, num lugar confinante, Gregorio Marañon, Prólogo a Escenas de la vida de un médico, Libros de Bolsillo Noguer, segunda edición, 1976: "El médico que no tenga el espíritu rígido y momificado por la pedantería y el dogmatismo, el médico que considere su saber con el debido, con el entrañable escepticismo, y, a través de este escepticismo, contemple y juzgue el inmenso espectáculo del mundo y del hombre que su prática le proporciona, no podrá menos de sentirse trascendido hasta la medula de los huesos por la tremenda tragedia del vivir."

${ }^{32}$ André Bay, Dimanche après-midi, Préface, Plon, Paris, 1966.

${ }^{33}$ Fundamental a este respeito: Elisabeth Kübler-Ross, On Death and Dying, Macmillan, New York, 1969.

${ }^{34}$ André Bay, Dimanche après-midi, Préface, Plon, Paris, 1966.

${ }^{35}$ vide nota 31.

${ }^{36}$ João Semana é uma figura de Júlio Dinis, com a sua aura de romantismo e bravura, impolidez e solicitude, acudindo à doença em lugarejos a que chegava, pelos idos de oitocentos, montado num animal fraterno, sem propósitos de índole antropológica ou interferência sócio-política. Não assim o protagonista de Retalhos, não assim os clínicos do legado de Fernando Namora que, no entanto, aqui e além (cumplicidade forjada nos anos de montanha agreste?) para si quis, guardadas as dissimilitudes, a designação popular.

“João-semana, s.m. Fig. Médico, especialmente o médico de aldeia, de costumes simples, um pouco rude." - José Pedro Machado, Grande Dicionário da Língua Portuguesa, Sociedade de Língua Portuguesa, Amigos do Livro, Lisboa, 1981.

No sentido acima expresso, ver, v.g., Alexandre Pinheiro Torres, O Neo-Realismo Literário Português (numa sequência polémica com António José Saraiva: O povo do Neo-Realismo não é o de Júlio Dinis), Moraes Editores, Lisboa, 1976.

${ }^{37}$ Jornal sem Data, corroborando: “Em medicina, o que será fundamental? Umas generalidades bem sólidas, bem arrumadas, das ciências afins - mas não há solidez sem simplificação (*). Depois, sim, carregar a fundo, a anatomia, a fisiologia, a patologia geral todas elas sem uma página em branco. 0 bom médico é o que observa um corpo um corpo e o vê, inteirinho, a funcionar - percebendo-lhe a teia dos nexos e o porquê de cada avaria, mesmo se the desconhece o nome apropriado.

Havia na minha terra um mecânico, homem de poucas falas. Vestia o fato-macaco como se fosse a sua segunda pele, nem o largava nos dias domingueiros. Chamavam-no para uma encrenca, ele punha o motor a trabalhar e, sempre sisudo, testa baixa, escutava as arritmias da máquina durante um bom pedaço. Depois, mais uns minutos de reflexão. E o diagnóstico não falhava, até da cidade vinham automobilistas confiar-lhe as carripanas empalamadas. Muitas vezes, nas minhas atribulações de João Semana, 
evocava o mestre Carniceiro a penetrar, sem ferramental que se visse, nos segredos dos motores $(* *) . "$

(*) - Onde iríamos se este excurso hermenêutico se deslocasse agora para a orografia estilística de Fernando Namora e a "difícil simplicidade" que sempre perseguiu.

(**) João Semana, aí o temos. No trajecto que vai de Condeixa ou Tinalhas a Monsanto, "nave de pedra”, e, pouco, ao Alentejo (Pavia), já singularizado quando amadurecem os alicerces de $O$ Trigo e o Joio.

${ }^{38}$ Ao acaso, nos Cadernos, uma vez que o índice de recorrência do vocabulário médico é, naturalmente, mais elevado nos escritos de especialidade, contos e romances como os preferidos na exposição oral.

“O homem, espevitado com o analéptico, pôs-se a esbracejar.” - URSS Mal Amada, Bem Amada.

"Um país em que a concorrência da mão-de-obra estrangeira, onde ela é escassa e cara, reacende abcessos que se supunha extintos." - Os Adoradores do Sol.

"Uma espécie de paranoia a que as tensões sociais podem, em muitos casos, oferecer um estandarte? Estamos no Vento.

"Muito pintada, a pintura escarnecia esses olhos embaciados pelos anos e pelo vício, essa boca lúbrica que o bâton ensanguentava, a lembrar os bordos de uma ferida que não cicatriza.” - Diálogo em Setembro.

“Creio que será sempre com um sentimento de perplexidade, de estranheza, e até de pudor violentado, que um autor se vê posto numa mesa anatómica, com as tripas de fora.” - Jornal sem Data.

E também: “sem precisar de sinais prodrómicos, de repente, 'sente-se’ [a velhice]”. Idem

“Aqui, em Francoforte, ou seja onde for, podemos identificá-los [“terceiras pessoas” às ordens de um empresário editorial] por sintomas ilusórios: uma distante condescendência no trato, um apuro formal de ministro em dia de inauguração, o gesto lento num ar de mercê que desvaloriza a vassalagem que Ihe é tributada." - Dispersos $I$.

- Fernando Namora, para quem a vocação comunicacional da linguagem na literatura era axial, afastou da sua escrita os alardes de tecnicalidade terminológica e, como tal, sem perda da pertinência na definição de patologias e respectivas manifestações clínicas, optava em regra por léxico ajustado ao contexto (fabulatório ou informativo, embebido nas elocuções correntes. Abundam os testemunhos, das páginas primígenas - com destaque para Retalhos, por terras do interior beirão - a Jornal sem Data, colectânea de papéis avulsos e obra-chave, de que vale transpor uma frase auto-dirigida sem transe nem ademanes emotivos: "Disseram-me, com gravidade acusadora e apreensiva, que eu tinha doença ruim”.

Doença ruim, falar comum da aldeia. Ou dessa aldeia grande que a cidade é. Não a etiologia e prognose do cancro intestinal, com cópia de detalhes identificadores que tão-só a um restrito círculo se destinaria. Opção deveras congruente com o homem e autor que foi. 